\title{
Nickel based electrocatalysts for oxygen evolution in high current density, alkaline water electrolysers
}

\author{
Xiaohong Li, ${ }^{* a}$ Frank C. Walsh ${ }^{a}$ and Derek Pletcher ${ }^{b}$ \\ Received 25th June 2010, Accepted 26th October 2010 \\ DOI: $10.1039 / \mathrm{c0cp00993h}$
}

A number of nickel based materials are investigated as potential oxygen evolution catalysts under conditions close to those met in modern, high current density alkaline water electrolysers.

Microelectrodes are used to avoid distortion of voltammetric data by IR drop even at the high current densities employed in such water electrolysers. High surface area nickel metal oxides prepared by cathodic deposition and mixed oxides prepared by thermal methods are considered. A mixed $\mathrm{Ni} / \mathrm{Fe}$ oxide is the preferred electrocatalyst. The influence of hydroxide ion concentration and temperature on the voltammetry is defined. Preliminary stability tests in a zero gap cell with an $\mathrm{OH}^{-}$conducting membrane show no significant increase in overpotential during 10 days operation in $4 \mathrm{M} \mathrm{NaOH}$ electrolyte at a current density of $1 \mathrm{~A} \mathrm{~cm}^{-2}$ at $333 \mathrm{~K}$.

\section{Introduction}

With advances in the development of membrane polymers able to conduct hydroxyl ions, there is renewed interest in electrocatalysts for oxygen evolution in alkaline media capable of long term operation at high current densities, maybe in excess of $1 \mathrm{~A} \mathrm{~cm}^{-2}$. It has long been recognised that water electrolysers utilising alkaline electrolytes have key advantages over acid technology; the electrocatalysts for both oxygen and hydrogen evolution need not contain precious metals and other cell components may be fabricated from low cost materials, thereby introducing substantial cost savings. The criteria for selecting the anode catalyst should include long term stability to corrosion in the cell (both on load and on open circuit), low cost and widely available materials together with a low overpotential for the electrode reaction.

Various aspects of anodic oxygen evolution and water electrolysis technology have been reviewed. ${ }^{1-5}$ Nickel based materials have been proposed as stable catalysts for oxygen evolution in alkaline media. These include high area forms of metallic nickel, ${ }^{6}$ 'oxide/hydroxide' layers produced via cathodic deposition, ${ }^{7-10}$ spinels $^{6,11,12}$ and perovskites ${ }^{6,13}$ prepared by thermal decomposition of transition metal salt solutions. However, the experiments reported were often carried out in different conditions and it is therefore difficult to make meaningful comparisons. Certainly, reliable data is limited to current densities much lower than those used in modern and developmental water electrolysers such as zero gap cells where the electrodes are sandwiched against an $\mathrm{OH}^{-}$ conducting membrane in order to minimise the voltage drop across the inter-electrode gap and hence the energy consumption. Such efficient cells are increasingly important to the hydrogen economy.

\footnotetext{
${ }^{a}$ Electrochemical Engineering Laboratory, School of Engineering Sciences, University of Southampton, Southampton, SO17 1BJ, UK. E-mail:Xh.Li@soton.ac.uk; Fax: +44-2380-597051;

Tel: + 44-2380-594905

${ }^{b}$ Electrochemistry Group, School of Chemistry, University of Southampton, Southampton SO17 1BJ, UK
}

In this paper, we report studies using uniform conditions close to those in a zero gap alkaline water electrolyser (strongly alkaline media, high current densities and elevated temperature, $353 \mathrm{~K}$ ). This is made possible by the use of microelectrodes that allow data to be obtained free of significant IR drop. Suitable electrocatalysts are identified and subjected to a preliminary long term test.

\section{Experimental}

Nickel(II) sulfate $\left(\mathrm{NiSO}_{4}\right.$, Aldrich, 99\%), nickel(II) nitrate $\left(\mathrm{Ni}\left(\mathrm{NO}_{3}\right)_{2}\right.$, Aldrich, $\left.99.999 \%\right)$, nickel(II) acetate $\left(\mathrm{Ni}\left(\mathrm{CH}_{3} \mathrm{COO}\right)_{2}\right.$, Fluka, $>99 \%$ ), cobalt(II) nitrate $\left(\mathrm{Co}\left(\mathrm{NO}_{3}\right)_{2}\right.$, Aldrich, $\left.\geq 99 \%\right)$, iron(II) sulfate $\left(\mathrm{FeSO}_{4}\right.$, Aldrich, $\left.\geq 99 \%\right)$, ammonium sulfate $\left(\left(\mathrm{NH}_{4}\right)_{2} \mathrm{SO}_{4}\right.$, Bio-LAB, 99.5\%), boric acid $\left(\mathrm{H}_{3} \mathrm{BO}_{3}, \mathrm{BDH}\right.$ Chemicals, $>99.5 \%$ ), sodium hydroxide $(\mathrm{NaOH}$, Fisher, $97 \%$ ), sodium acetate $\left(\mathrm{CH}_{3} \mathrm{COONa}\right.$, Fluka, >99.5\%), non-ionic surfactant Brij $56\left(\mathrm{C}_{16}[\mathrm{EO}]_{n}\right.$ where $n \sim 10$, Aldrich), and other transition metal sulfate chemicals were all used as received. All aqueous solutions were freshly prepared with ultra pure water (18 $\mathrm{M} \Omega \mathrm{cm}$ resistivity) from an Elga water purification system.

Electrochemical measurements were carried out using an Autolab potentiostat/galvanostat PGSTAT30 in a small undivided beaker cell (volume $50 \mathrm{~cm}^{3}$ ) equipped with a water jacket connected to a Camlab W14 water thermostat. A nickel or steel microdisc electrode, a large area platinum gauze and a mercury/mercury oxide electrode $(\mathrm{Hg} / \mathrm{HgO}$ in $1 \mathrm{M} \mathrm{NaOH})$ were used as working, counter and reference electrodes, respectively. The reference electrode was always at the same temperature as the working electrode. The microdisc electrodes were made of a nickel wire (Goodfellow, purity 99.0\%, $50 \mu \mathrm{m}$ diameter) or a stainless steel wire (Goodfellow, $50 \mu \mathrm{m}$ diameter) that was sealed in glass, giving a cross-sectional area $\approx 2 \times 10^{-5} \mathrm{~cm}^{2}$. Prior to use, they were polished using alumina powder (Buehler) in three grades: $1 \mu \mathrm{m}, 0.3 \mu \mathrm{m}$, and $0.05 \mu \mathrm{m}$ then rinsed well with deionized water. All current densities in this paper are based on the apparent geometric area of the electrodes. 
The cathodic deposition of various metal/mixed metal oxide/ hydroxide films was conducted at room temperature $(295 \pm 2 \mathrm{~K})$ under galvanostatic control from two media. (i) For some preliminary experiments, nitrate solutions were used ${ }^{7}$ with a current density $8 \mathrm{~mA} \mathrm{~cm}^{-2}$ for $10 \mathrm{~s}$. $\mathrm{Ni}(\mathrm{OH})_{2}$ was deposited from $0.1 \mathrm{M} \mathrm{Ni}\left(\mathrm{NO}_{3}\right)_{2}$ solution and the mixed $\mathrm{Ni} / \mathrm{Fe}(\mathrm{OH})_{2}$ from a solution containing $0.1 \mathrm{M} \mathrm{Ni}\left(\mathrm{NO}_{3}\right)_{2}$ and $0.01 \mathrm{M} \mathrm{Fe}\left(\mathrm{NO}_{3}\right)_{3}$. (ii) Most electrodes were prepared in a sulfate medium ${ }^{9}$ using current densities in the range $10-500 \mathrm{~mA} \mathrm{~cm}^{-2}$ and deposition times in the range $10-200 \mathrm{~s}$ at an initial $\mathrm{pH}$ of 2-6. Most commonly, the deposition used $250 \mathrm{~mA} \mathrm{~cm}^{-2}$ for $50 \mathrm{~s}$ $\left(12.5 \mathrm{mC} \mathrm{cm}^{-2}\right)$ and the solution a total of $18 \mathrm{mM}$ transition metal ions as well as $25 \mathrm{mM}\left(\mathrm{NH}_{4}\right)_{2} \mathrm{SO}_{4}$ at $\mathrm{pH} 4$.

Mesoporous nickel films were prepared by using a lyotropic liquid crystalline mesophase of a non-ionic surfactant (Brij 56) as a template. ${ }^{14,15}$ The mesoporous films were electrodeposited at room temperature using a potentiostatic method at a potential of $-0.9 \mathrm{~V} \quad v s$. a saturated calomel reference electrode for $2 \mathrm{~h}$ from a liquid crystalline templating mixture containing $65 \mathrm{wt} \%$ Brij56 and $35 \mathrm{wt} \%$ aqueous solution consisting of $0.2 \mathrm{M} \mathrm{Ni}\left(\mathrm{CH}_{3} \mathrm{COO}\right)_{2}, 0.5 \mathrm{M} \mathrm{CH} \mathrm{CHONa}_{3} \mathrm{CO}$, $0.2 \mathrm{M} \mathrm{H}_{3} \mathrm{BO}_{3}$. After deposition the film was soaked in isopropanol for at least $24 \mathrm{~h}$ to remove the surfactant from the pores. Spinel $\mathrm{NiCo}_{2} \mathrm{O}_{4}$ layers were prepared by a thermal decomposition technique. ${ }^{16}$ The preparation procedure was: (i) a solution containing $0.5 \mathrm{M} \mathrm{Ni}\left(\mathrm{NO}_{3}\right)_{2}$ and $1 \mathrm{M} \mathrm{Co}\left(\mathrm{NO}_{3}\right)_{2}$ was sprayed onto the substrate immediately after its removal from a furnace at $573 \mathrm{~K}$ using a Badger airless spray gun; (ii) the sample was dried at $298 \mathrm{~K}$ for $30 \mathrm{~min}$; (iii) the sample was placed into a furnace for thermal decomposition at $573 \mathrm{~K}$ for 10 min; (iv) the steps (i) to (iii) were repeated 5 times, (v) the sample was annealed at $573 \mathrm{~K}$ for $90 \mathrm{~min}$.

The surface morphology and composition of the prepared films were characterized using a Philips XL30 scanning electron microscope (SEM) equipped with energy dispersive X-ray (EDX) microanalysis (Oxford Inca 300) and operated at an accelerating voltage of $15 \mathrm{kV}$. The ratio of transition metals in the mixed films was determined by EDX using samples that were deposited onto $1 \mathrm{~cm}^{2}$ gold on glass plates. These were prepared by evaporating a gold film (200 nm thickness) onto glass with a thin $(15 \mathrm{~nm})$ adhesive underlayer of chromium. Before use, these electrodes were cleaned by sonicating in isopropanol for $60 \mathrm{~min}$.

Preliminary lifetime testing of anode electrocatalysts was carried out using cells with alkaline membranes fabricated by ITM Power plc, UK. The cell was assembled with the two gauze electrodes (each geometric area, $9 \mathrm{~cm}^{2}$ ) pressed up against the membrane and $4 \mathrm{M} \mathrm{NaOH}$ flowed down the rear of the gauzes at a flow rate of $15 \mathrm{~cm}^{3} \mathrm{~min}^{-1}$ to prevent gas accumulation. The anode was a fine stainless steel mesh (DeXmet Corporation, 4SS 5-050) coated with Ni/Fe oxide and the cathode a stainless steel mesh coated with platinum. The tests were carried out at $333 \mathrm{~K}$ and ambient pressure.

\section{Results and discussion}

Fig. 1 reports voltammograms for a smooth Ni surface in $1 \mathrm{M}$ $\mathrm{NaOH}$ at three temperatures $(298 \mathrm{~K}, 333 \mathrm{~K}$ and $353 \mathrm{~K})$. At each temperature, a well formed, symmetrical anodic peak is

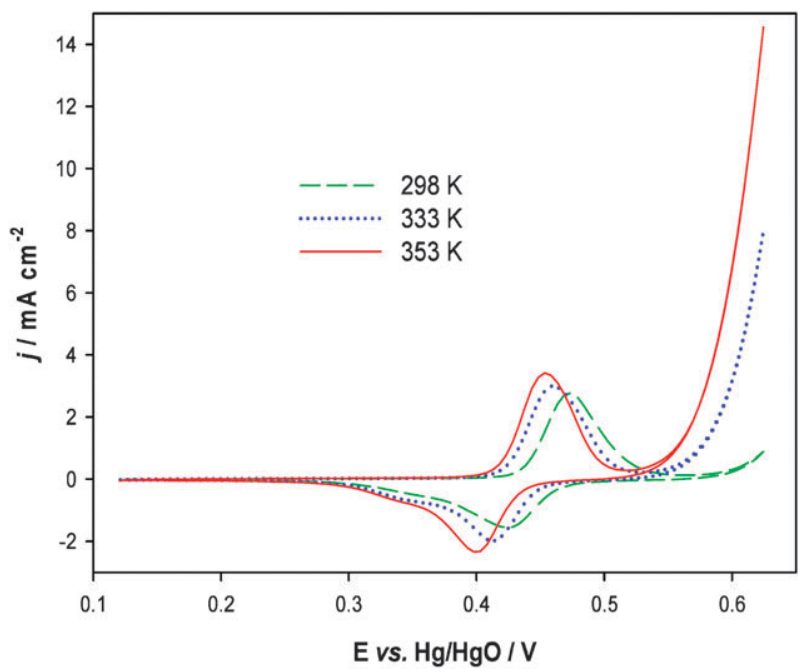

Fig. 1 Cyclic voltammograms recorded at a polished nickel electrode in $1 \mathrm{M} \mathrm{NaOH}$ at three temperatures $(298 \mathrm{~K}, 333 \mathrm{~K}$, and $353 \mathrm{~K})$. Potential sweep rate: $100 \mathrm{mV} \mathrm{s}^{-1}$.

seen on the scan to more positive potentials and a coupled symmetrical cathodic peak on the reverse scan. The charges associated with the anodic and cathodic peaks are equal and the peak current densities are proportional to the potential scan rate. These observations are consistent with a surface conversion, generally written in the literature ${ }^{17}$

$$
\mathrm{Ni}(\mathrm{OH})_{2}+\mathrm{OH}^{-}-\mathrm{e}^{-} \rightleftarrows \mathrm{NiO}(\mathrm{OH})+\mathrm{H}_{2} \mathrm{O}
$$

where $\mathrm{Ni}(\mathrm{OH})_{2}$ is formed spontaneously when the $\mathrm{Ni}$ is placed into the electrolyte. It can be seen that there is only a small shift in the peak potential with temperature and charge associated with complete oxidation is also only a slight function of temperature. The charge is $\sim 1 \mathrm{mC} \mathrm{cm}^{-2}$ equivalent to the oxidation of a few monolayers on an atomically flat surface or

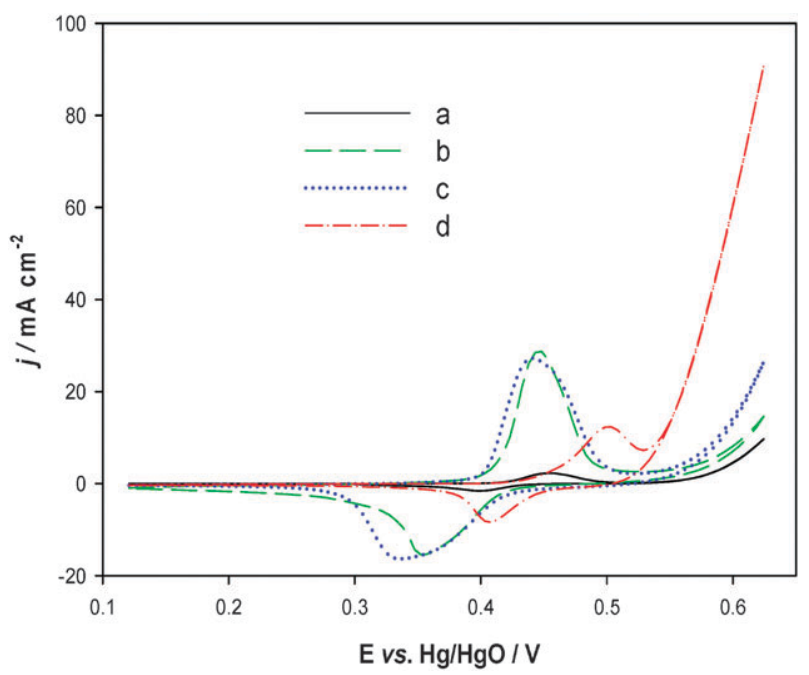

Fig. 2 Cyclic voltammograms recorded in $1 \mathrm{M} \mathrm{NaOH}$ at $353 \mathrm{~K}$ at four electrodes: (a) polished $\mathrm{Ni}$ (b) a mesoporous $\mathrm{Ni}$ layer deposited from a lyotropic liquid crystal phase (c) a $\mathrm{Ni}(\mathrm{OH})_{2}$ layer deposited cathodically from nitrate solution (d) a mixed $\mathrm{Ni} / \mathrm{Fe}(\mathrm{OH})_{2}$ layer deposited cathodically from nitrate solution. Potential sweep rate: $100 \mathrm{mV} \mathrm{s}^{-1}$. 


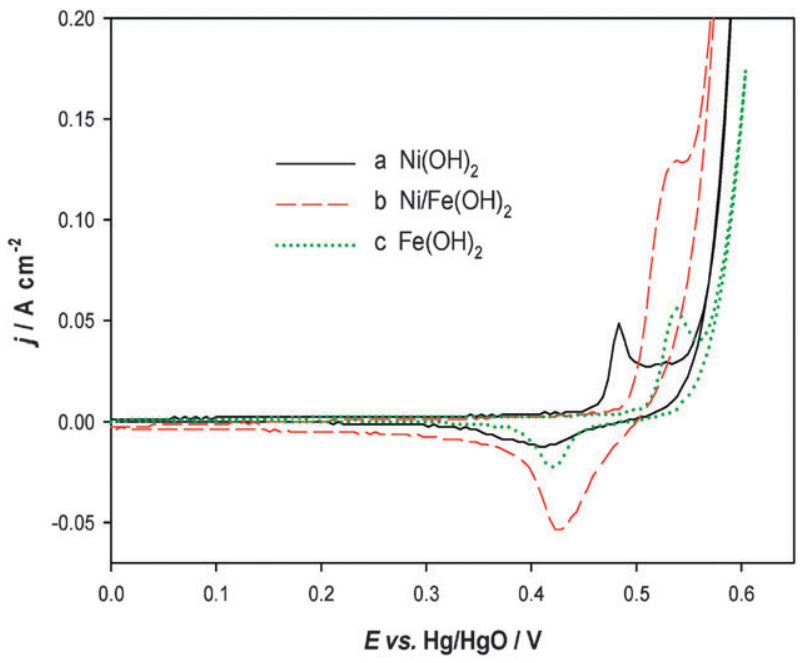

Fig. 3 Cyclic voltammograms recorded in $1 \mathrm{M} \mathrm{NaOH}$ at $353 \mathrm{~K}$ at a potential sweep rate $100 \mathrm{mV} \mathrm{s}^{-1}$ at three hydroxide layers. The hydroxide layers were cathodically deposited at $250 \mathrm{~mA} \mathrm{~cm}{ }^{-2}$ for $50 \mathrm{~s}$ at $295 \mathrm{~K}$ on a $\mathrm{Ni}$ microdisc electrode in electrolyte solutions containing (a) $18 \mathrm{mM} \mathrm{NiSO}_{4}$ (b) $9 \mathrm{mM} \mathrm{NiSO}_{4}+9 \mathrm{mM} \mathrm{FeSO}_{4}$ (c) $18 \mathrm{mM} \mathrm{FeSO}_{4}$. All also contained $25 \mathrm{mM}\left(\mathrm{NH}_{4}\right)_{2} \mathrm{SO}_{4}$.

a monolayer on a slightly rough surface. In contrast to the surface conversion, the current density for oxygen evolution,

$$
4 \mathrm{OH}^{-}-4 \mathrm{e}^{-} \rightarrow \mathrm{O}_{2}+2 \mathrm{H}_{2} \mathrm{O}
$$

at potentials positive to $+0.4 \mathrm{~V} v s$. SCE depends strongly on temperature. The thermodyamics of $\mathrm{O}_{2}$ evolution are not significantly influenced by temperature and hence the increase in current density arises largely from an increase in the kinetics of oxygen evolution with temperature.

Fig. 2 compares the voltammograms in $1 \mathrm{M} \mathrm{NaOH}$ at $353 \mathrm{~K}$ for (a) a polished $\mathrm{Ni}$ surface (b) a mesoporous $\mathrm{Ni}$ layer deposited from a lyotropic liquid crystal phase (c) a $\mathrm{Ni}(\mathrm{OH})_{2}$ layer deposited cathodically from a $\mathrm{Ni}\left(\mathrm{NO}_{3}\right)_{2}$ solution (d) a mixed $\mathrm{Ni} / \mathrm{Fe}(\mathrm{OH})_{2}$ layer deposited in similar conditions from a nitrate medium containing both $\mathrm{Ni}$ (II) and $\mathrm{Fe}(\mathrm{II})$. On the current density scale of this figure, the response for the smooth $\mathrm{Ni}$ is barely visible. The voltammograms for (b) and (c) both give a much larger peak for the surface conversion, reaction (1), but for different reasons. For the mesoporous $\mathrm{Ni}$ layer, the increase charge results from its high surface area within the pores. ${ }^{14,15}$ For the cathodically deposited layer, the oxidation probably occurs throughout a three dimensional layer of the hydroxide. Both layers catalyse $\mathrm{O}_{2}$ evolution better than polished $\mathrm{Ni}$ but the increases in current density, particularly for the mesoporous deposit, are modest. The results for the mixed $\mathrm{Ni} / \mathrm{Fe}$ oxide layer are more interesting. It can be seen that the peaks for the surface interconversion are shifted to more positive potentials - the mixed $\mathrm{Ni} / \mathrm{Fe}$ hydroxide layer is more difficult to oxidise and the reduction also shifts positive implying a change in the thermodynamics for the oxide change. The charges associated with the oxidation and reduction are also smaller than for the pure $\mathrm{Ni}(\mathrm{OH})_{2}$ layer. On the other hand, the current density for oxygen evolution is much higher than for the other surfaces - the Fe(II) introduced into the layer is truly enhancing the catalytic activity of the

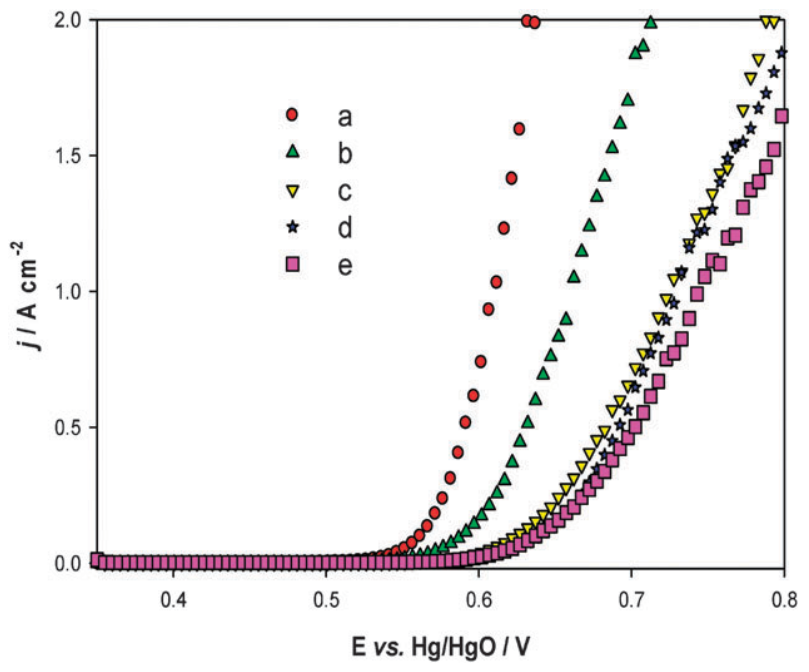

Fig. 4 Steady state polarization curves recorded in $1 \mathrm{M} \mathrm{NaOH}$ at $353 \mathrm{~K}$ for (a) a mixed $\mathrm{Ni} / \mathrm{Fe}(\mathrm{OH})_{2}$ layer deposited from the sulfate solution using a cathodic current density of $250 \mathrm{~mA} \mathrm{~cm}^{-2}$ for $50 \mathrm{~s} \mathrm{(b)} \mathrm{a}$ $\mathrm{NiCo}_{2} \mathrm{O}_{4}$ spinel prepared thermally in similar conditions from a nitrate medium containing both $\mathrm{Ni}$ (II) and $\mathrm{Co}$ (II) (c) a mesoporous Ni layer (d) a polished nickel microdisc and (e) a polished stainless steel microdisc. Potential sweep rate: $1 \mathrm{mV} \mathrm{s}^{-1}$.

coating. Fig. 3 compares the voltammograms for $\mathrm{Ni}(\mathrm{OH})_{2}$, $\mathrm{Fe}(\mathrm{OH})_{2}$ and $\mathrm{Ni} / \mathrm{Fe}(\mathrm{OH})_{2}$ layers. In fact the iron is likely to be present as $\mathrm{Fe}(\mathrm{III})$ at the negative potential limit. It can be seen that although $\mathrm{Ni}(\mathrm{OH})_{2}$ is oxidised more readily than $\mathrm{Fe}(\mathrm{OH})_{3}$, it is the potential of an $\mathrm{Fe}$ (III)/ $\mathrm{Fe}$ (IV) that determines the potential for the oxidation of the mixed $\mathrm{NiFe}(\mathrm{OH})_{2}$; this may arise because the $\mathrm{Fe}(\mathrm{OH})_{3}$ is poorly conducting before it is converted into a higher oxide.

The catalytic activity of various surfaces for oxygen evolution was assessed by recording voltammograms at microdisc electrodes (to minimise distortion by IR drop) at a temperature of $353 \mathrm{~K}$ in $1 \mathrm{M} \mathrm{NaOH}$ using a potential scan rate

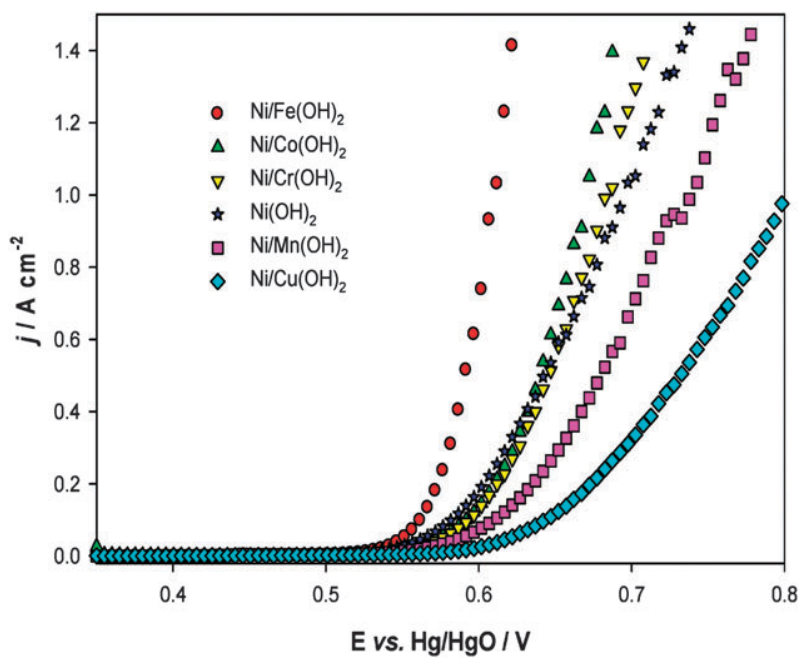

Fig. 5 Steady state polarization curves recorded for various coatings on a Ni microdisc electrode in $1 \mathrm{M} \mathrm{NaOH}$ at $353 \mathrm{~K}$. The layers were cathodically deposited at $250 \mathrm{~mA} \mathrm{~cm}{ }^{-2}$ for $50 \mathrm{~s}$ at $298 \mathrm{~K}$ on $\mathrm{Ni}$ microdisc electrode in sulfate media containing $9 \mathrm{mM} \mathrm{NiSO}_{4}+9 \mathrm{mM}$ $\mathrm{MSO}_{4}+25 \mathrm{mM}\left(\mathrm{NH}_{4}\right)_{2} \mathrm{SO}_{4}$. Potential sweep rate: $1 \mathrm{mV} \mathrm{s}{ }^{-1}$. 


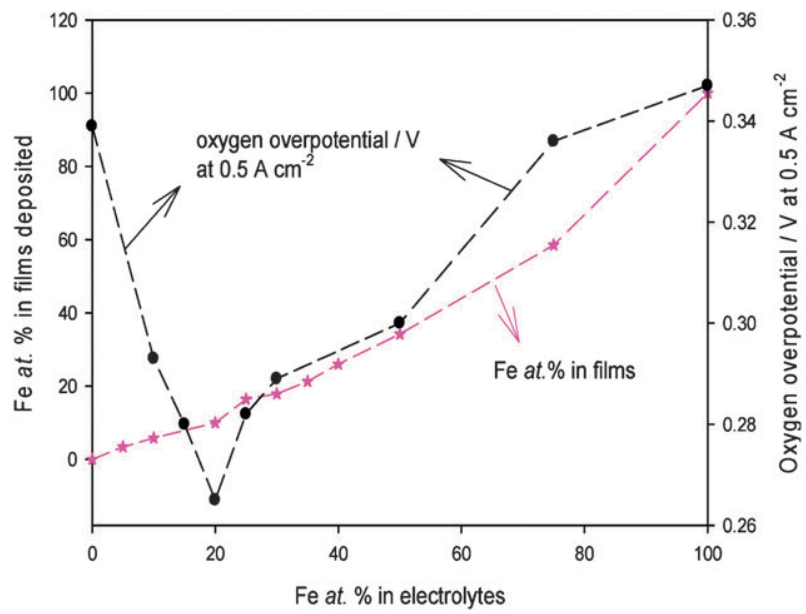

Fig. 6 Influence of the ratio of $\mathrm{Ni}(\mathrm{II}): \mathrm{Fe}(\mathrm{II})$ in solution on the composition of the layer formed and the overpotential for oxygen evolution in $1 \mathrm{M} \mathrm{NaOH}$ at $353 \mathrm{~K}$. Deposition conditions: cathodic current density $250 \mathrm{~mA} \mathrm{~cm}{ }^{-2}$ for $50 \mathrm{~s}$ at $298 \mathrm{~K}$ on gold substrates in sulfate media containing a total of $18 \mathrm{mM}$ transition metal ions $+25 \mathrm{mM}\left(\mathrm{NH}_{4}\right)_{2} \mathrm{SO}_{4}$.

of $1 \mathrm{mV} \mathrm{s}^{-1}$. Fig. 4 shows illustrative voltammograms for (a) a mixed $\mathrm{Ni} / \mathrm{Fe}(\mathrm{OH})_{2}$ layer deposited onto a $\mathrm{Ni}$ microdisc from the sulfate solution using a cathodic current density of $250 \mathrm{~mA}$ $\mathrm{cm}^{-2}$ for $50 \mathrm{~s}$ (b) a $\mathrm{NiCo}_{2} \mathrm{O}_{4}$ spinel prepared thermally on a microwire electrode (c) a mesoporous $\mathrm{Ni}$ layer on a steel microdisc (d) a polished nickel microdisc and (e) a polished stainless steel microdisc. It should be noted that the current density range is extended up to $2 \mathrm{~A} \mathrm{~cm}^{-2}$ since it is expected to operate water electrolysers in the range $0.5-2 \mathrm{~A} \mathrm{~cm}^{-2}$. Significant catalysis of $\mathrm{O}_{2}$ evolution compared to bare nickel and stainless steel is exhibited by both the mixed $\mathrm{NiFe}(\mathrm{OH})_{2}$ layer and the spinel but the former clearly gives the lowest overpotential.

The experiment was repeated for a number of mixed hydroxides of nickel where the other transition metal was varied, see Fig. 5; catalysis increased in the order $\mathrm{Cu}(\mathrm{II})<$ $\mathrm{Mn}(\mathrm{II})<\mathrm{Cr}(\mathrm{II})<\mathrm{Co}(\mathrm{II})<\mathrm{Fe}(\mathrm{II})$ with the $\mathrm{Fe}(\mathrm{II})$ containing

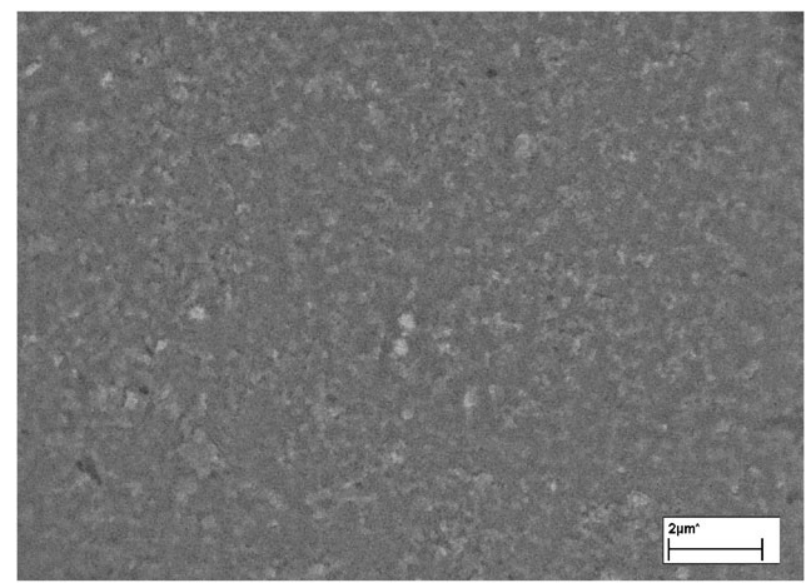

Fig. 7 SEM image of a $\mathrm{NiFe}(\mathrm{OH})_{2}$ layer cathodically deposited at $250 \mathrm{~mA} \mathrm{~cm}^{-2}$ for $50 \mathrm{~s}$ at $295 \mathrm{~K}$ on a stainless steel microdisc electrode in an electrolyte solution containing $14.4 \mathrm{mM} \mathrm{NiSO}_{4}+3.6 \mathrm{mM} \mathrm{FeSO}_{4}+$ $25 \mathrm{mM}\left(\mathrm{NH}_{4}\right)_{2} \mathrm{SO}_{4}$.
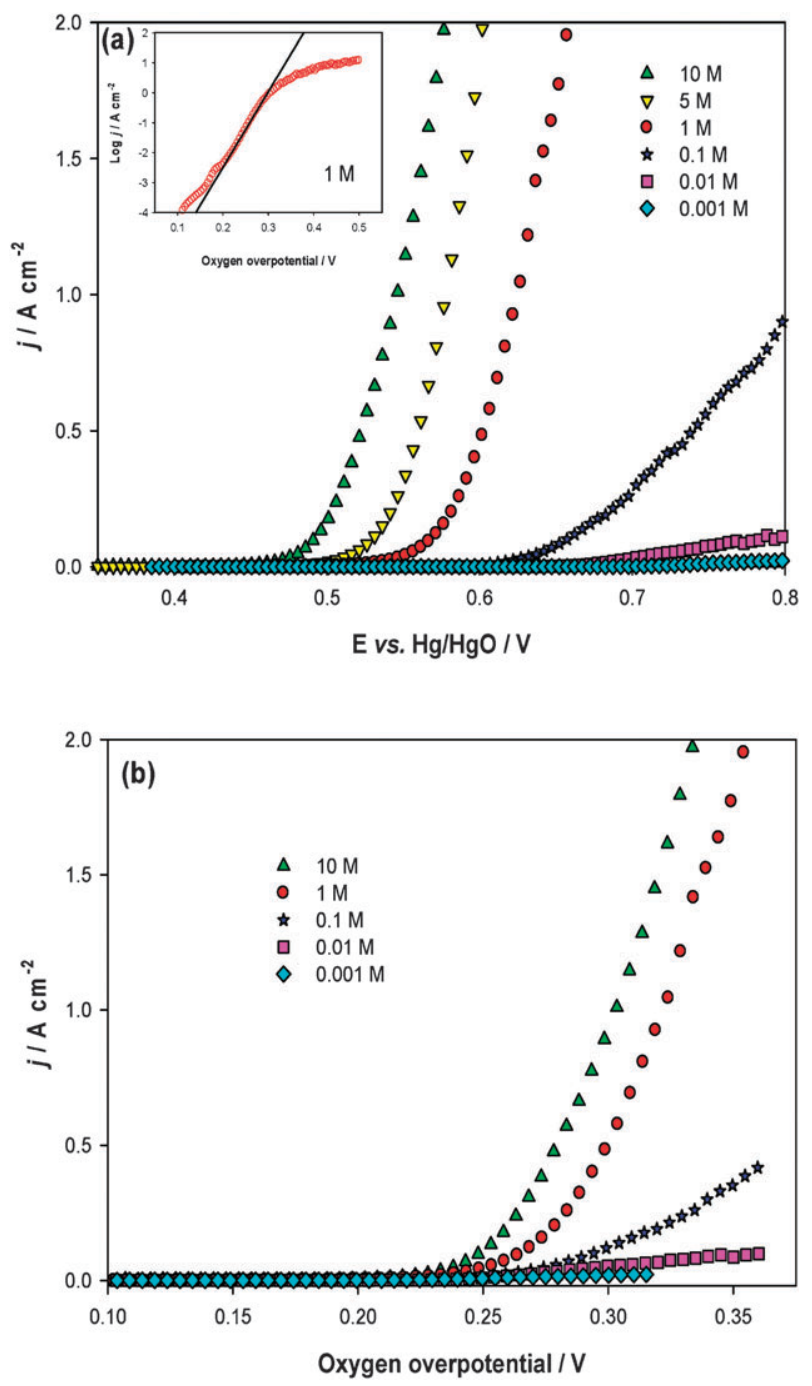

Fig. 8 (a) Steady state polarization curves recorded at a $\mathrm{NiFe}(\mathrm{OH})_{2}$ layer in $\mathrm{NaOH}$ electrolytes with various concentrations at $353 \mathrm{~K}$. Potential sweep rates: $1 \mathrm{mV} \mathrm{s}^{-1}$. The $\mathrm{NiFe}(\mathrm{OH})_{2}$ layer was cathodically deposited at $250 \mathrm{~mA} \mathrm{~cm}^{-2}$ for $50 \mathrm{~s}$ at $298 \mathrm{~K}$ on a Ni microdisc electrode in an electrolyte solution containing $9 \mathrm{mM} \mathrm{NiSO}_{4}+9 \mathrm{mM} \mathrm{FeSO}_{4}+$ $25 \mathrm{mM}\left(\mathrm{NH}_{4}\right)_{2} \mathrm{SO}_{4}$. The inset shows the data for $1 \mathrm{M} \mathrm{NaOH}$ presented as a Tafel plot. (b) Data replotted as current density versus overpotential.

layer showing the best performance. Since the lowest overpotential was obtained with the mixed $\mathrm{NiFe}(\mathrm{OH})_{2}$ layer, the influence of the preparation conditions on the performance for oxygen evolution was investigated. The parameters varied included the composition of the electrolyte (sulfate $v s$. nitrate, concentration of electrolyte, initial $\mathrm{pH}$, absolute concentration of the metals, the ratio of $\mathrm{Fe}(\mathrm{II})$ : $\mathrm{Ni}(\mathrm{II})$, current density and deposition time). These experiments are illustrated in Fig. 6 which shows the influence of the ratio of $\mathrm{Ni}(\mathrm{II}): \mathrm{Fe}$ (II) in the solution to the ratio of $\mathrm{Ni}$ (II) : $\mathrm{Fe}$ (II) in the layer formed by cathodic deposition. A gold substrate was used so that the $\mathrm{Ni}$ : Fe ratio in the bulk deposits would be determined by EDX without interference from the substrate. Over much of range, the $\mathrm{Fe}(\mathrm{II})$ content of the deposit varies almost linearly with the $\mathrm{Fe}(\mathrm{II})$ in the electrolyte and the plot has a slope close to 0.5 . 


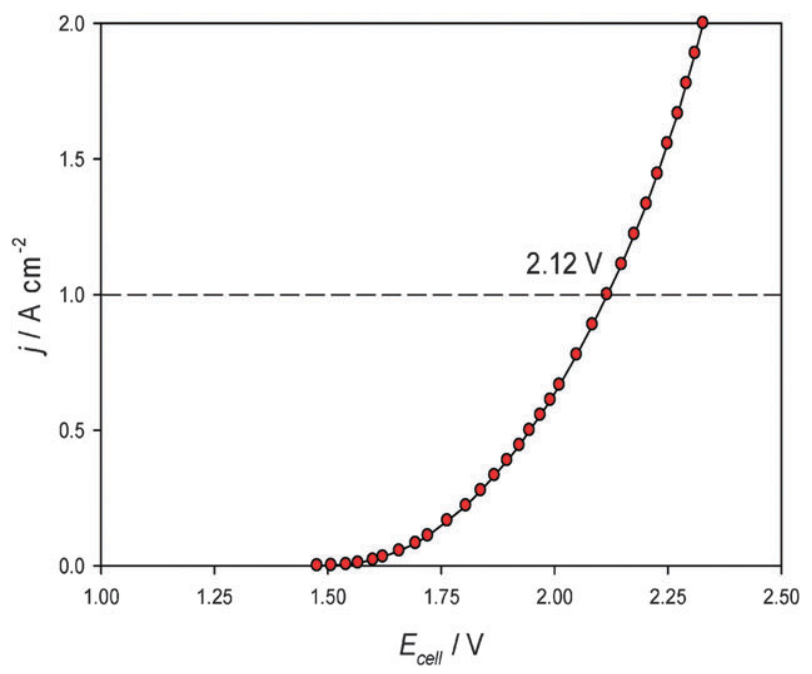

Fig. 9 Steady state cell current density $v s$. cell voltage plot for a cell with a $9: 1 \mathrm{Ni}$ (II): $\mathrm{Fe}$ (II) coating on the stainless steel anode, a Pt coated stainless steel cathode and a developmental $\mathrm{OH}^{-}$membrane $(160 \mu \mathrm{m}$ thickness). Electrolyte: $4 \mathrm{M} \mathrm{NaOH}$. Temperature: $333 \mathrm{~K}$.

For a current density of $0.5 \mathrm{~A} \mathrm{~cm}^{-2}$, the oxygen evolution overpotential varies between $265 \mathrm{mV}$ and $330 \mathrm{mV}$ with the lowest overpotential being found for the layer containing a $\mathrm{Ni}(\mathrm{II}): \mathrm{Fe}(\mathrm{II})$ ratio of $9: 1$ (corresponding to $20 \% \mathrm{Fe}$ (II) in solution). More generally, the coatings formed under all conditions were effective catalysts for $\mathrm{O}_{2}$ evolution in $1 \mathrm{M}$ $\mathrm{NaOH}$ with the overpotentials at a current density of $0.5 \mathrm{~A} \mathrm{~cm}^{-2}$ in the range $265-400 \mathrm{mV}$. The lowest overpotential was obtained using a coating deposited using: an electrolyte containing $14.4 \mathrm{mM} \mathrm{NiSO} 4+3.6 \mathrm{mM} \mathrm{FeSO}_{4}+25 \mathrm{mM}$ $\left(\mathrm{NH}_{4}\right)_{2} \mathrm{SO}_{4}, \mathrm{pH} 4$, a current density of $250 \mathrm{~mA} \mathrm{~cm}{ }^{-2}$ for $50 \mathrm{~s}$ and drying by standing under ambient conditions ( $295 \pm 2 \mathrm{~K})$. The topography of the coating produced on a steel microelectrode under these conditions is shown in Fig. 7. The coating is uniform and smooth; EDX mapping of the surface confirmed that the composition is uniform across the microdisc.

Fig. 8(a) shows the influence of hydroxyl ion concentration on the voltammogram of an $\mathrm{NiFe}(\mathrm{OH})_{2}$ coating. There is a strong shift in the current for oxygen evolution towards more negative potentials with increase in the hydroxide ion concentration. This partially arises from a change in the thermodynamics of the oxygen evolution reaction, i.e. the $60 \mathrm{mV}$ per $\mathrm{pH}$ unit shift in the equilibrium potential but it is also clear that there is an enhancement in the reaction kinetics as can be seen when the data is replotted as a function of overpotential, Fig. 8(b). The inset in Fig. 8(a) shows the data for $1 \mathrm{M} \mathrm{NaOH}$ presented as a Tafel plot. A linear Tafel with a slope of $33 \mathrm{mV} \mathrm{dec}^{-1}$ is observed over two orders of magnitude of current density up to almost $1 \mathrm{~A}$ $\mathrm{cm}^{-2}$. Above this current density, the voltammogram tends towards a plateau; whether this is due, even at a microelectrode, to an IR drop (possibly due to evolved gas?) or a mass transport limitation on the hydroxide ion is not clear. The Tafel slopes reported in the literature ${ }^{7-9,18}$ cover a lower current density range and widely different values can be found. Two papers ${ }^{8,9}$ also report large variations in Tafel slope with the composition of $\mathrm{NiFe}(\mathrm{OH})_{2}$ which we did not observe. We believe

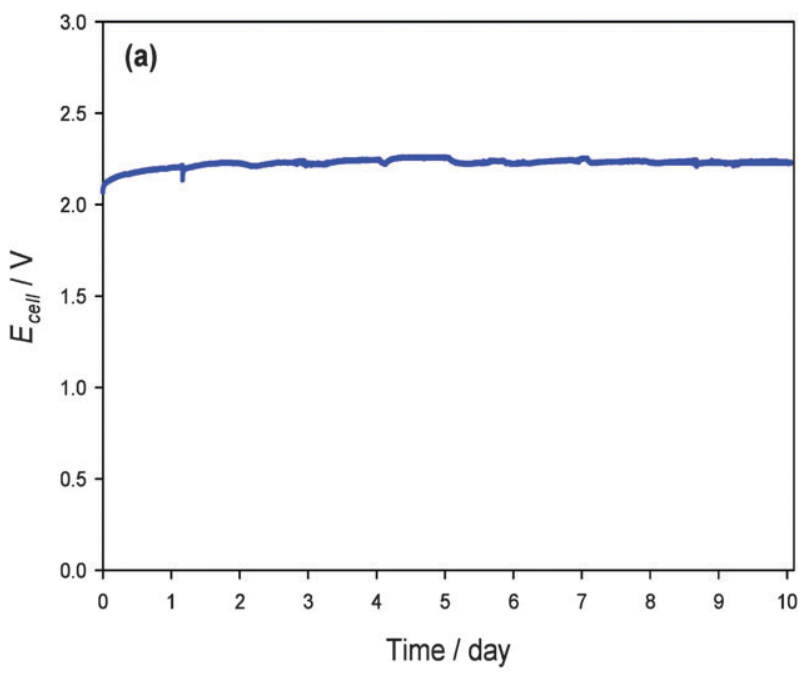

(b)

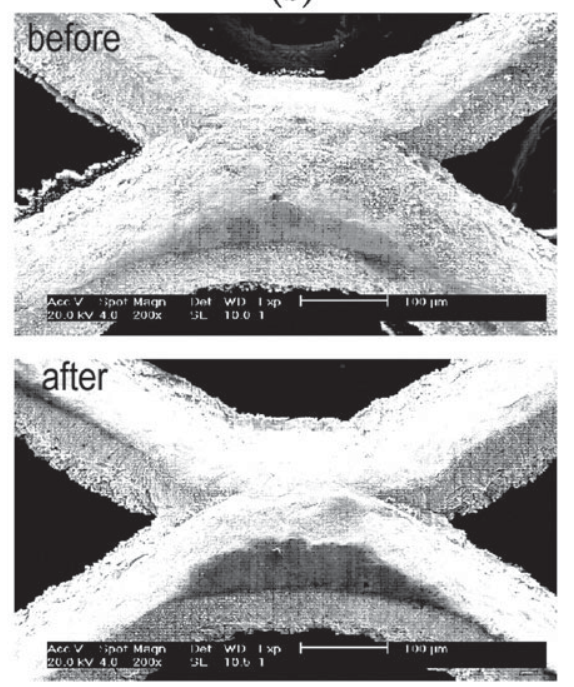

Fig. 10 (a) Cell voltage as a function of time for the zero gap water electrolysis cell with a $9: 1 \mathrm{Ni}(\mathrm{II}): \mathrm{Fe}(\mathrm{II})$ coating on the stainless steel anode, a Pt coated stainless steel cathode and a development $\mathrm{OH}^{-}$ membrane (160 $\mu \mathrm{m}$ thickness). Electrolysis was carried out at $1 \mathrm{~A} \mathrm{~cm}^{-2}$ in $4 \mathrm{M} \mathrm{NaOH}$ at $333 \mathrm{~K}$. (b) The SEM images are for the anode mesh before and after the 10 days electrolysis.

that our values are more reliable since the microelectrode technique employed provides a very low uncompensated ohmic drop between working and reference electrodes.

In order to undertake preliminary lifetime testing of the mixed hydroxide coating containing $\mathrm{Ni}(\mathrm{II})$ and $\mathrm{Fe}(\mathrm{II})$, the coating was deposited onto a fine stainless steel mesh, area $9 \mathrm{~cm}^{2}$. Cells were constructed where a $\mathrm{OH}^{-}$conducting membrane was compressed between a platinised stainless steel mesh and the mixed $\mathrm{NiFe}(\mathrm{OH})_{2}$ coated stainless steel mesh and feeding $4 \mathrm{M} \mathrm{NaOH}$ to the back side of both electrodes. The membrane is still undergoing optimisation and is not available commercially. By eye, the coatings on the steel mesh are black and uniform and the coatings show good adhesion. Fig. 9 shows a current density vs. cell voltage curve for a zero gap cell, in fact with an anode coated with the $\mathrm{NiFe}(\mathrm{OH})_{2}$ layer coated under the optimum conditions from 
Table 1 Comparison of oxygen overpotentials at a selection of anode materials in $1 \mathrm{M} \mathrm{NaOH}$ at $353 \mathrm{~K}$

\begin{tabular}{lll}
\hline $\mathrm{Ni}$ based catalysts & Method of preparation & Oxygen overpotential $/ \mathrm{mV}$ at $0.5 \mathrm{~A} \mathrm{~cm}^{-2}$ \\
\hline Stainless steel & Polishing & 400 \\
$\mathrm{Smooth} \mathrm{Ni}$ & Polishing & 389 \\
Mesoporous Ni coating & Electrodeposition & 380 \\
$\mathrm{Spinel} \mathrm{NiCo}_{2} \mathrm{O}_{4}$ coating & Thermal decomposition & 329 \\
$\mathrm{Ni}(\mathrm{OH})_{2}$ coating & Electrodeposition & 339 \\
$\mathrm{Fe}(\mathrm{OH})_{2}$ coating & Electrodeposition & 347 \\
$\mathrm{Ni} / \mathrm{Fe}(\mathrm{OH})_{2}$ coating & Electrodeposition & 265 \\
\hline
\end{tabular}

this study. The cell voltage is $2.12 \mathrm{~V}$ at $1 \mathrm{~A} \mathrm{~cm}^{-2}$. Fig. 10(a) reports the cell voltage as a function of time over a 10 day period for the cell with the mixed $\mathrm{Ni} / \mathrm{Fe}$ hydroxide coated anode. It can be seen that the cell voltage keeps stable in the range of $2.10 \mathrm{~V}$ to $2.25 \mathrm{~V}$ during the whole period of investigation and there was no evidence for deactivation or degradation of the electrode performance. Moreover, current density $v s$. cell voltage plots were identical before and after the test; SEM (see Fig. 10(b)) also indicated no observable degradation in the coating morphology.

\section{Conclusions}

The electrocatalysts produced by the cathodic co-precipitation of $\mathrm{Ni}$ (II) and $\mathrm{Fe}$ (II) hydroxide give the lowest overpotential for oxygen evolution in alkaline media, see Table 1 . This was also the conclusion of Merrill and Dougherty ${ }^{9}$ although there are significant differences between the voltammetry of these workers and ourselves and these would lead to different conclusions both about the mechanism and the prospects for a further reduction in the overpotential. We believe that while $\mathrm{NiFe}(\mathrm{OH})_{2}$ is a good catalyst, further decreases in overpotential would be highly beneficial to water electrolysis technology and these are only likely to be achieved by the identification of new families of catalysts. It is interesting to note that while small additions of $\mathrm{Fe}$ (II) to the Ni(II) enhanced the rate of oxygen evolution larger additions reduced the advantage until the coating containing mostly $\mathrm{Fe}(\mathrm{II})$ were worse than those containing $\mathrm{Ni}(\mathrm{II})$ alone.

The $\mathrm{NiFe}(\mathrm{OH})_{2}$ catalyst is low cost and easily deposited onto a number of substrates (including nickel and steels) even if the substrate has a complex shape. The catalysts have been shown to be completely stable over 10 days of electrolysis and it should be recognised that this stability test was only terminated so that the equipment could be used for other experiments. It should again be stressed that the data of Fig. 9 and 10 is presented only to demonstrate the stability of the anode catalyst. Overall, we believe that the $\mathrm{NiFe}(\mathrm{OH})_{2}$ anode catalyst could make a significant contribution to the development of low cost and energy efficient alkaline water electrolysers. Further decreases in cell voltage can be achieved by improvements to the membrane and cathode catalyst as well as changes to electrodes and cell design.

This paper also demonstrates the advantages of using microelectrodes to develop an understanding of practical electrochemical processes. In electrochemical technology, the current densities are usually sufficiently large that IR drop through the electrolyte solution becomes a problem and techniques for estimating and/or correcting for IR drop can be unreliable and difficult to apply. In water electrolysis, there are also the additional problems posed by the high rate of gas evolution. In this work, we have routinely recorded very large current densities and there is no evidence of IR drop effects below $1 \mathrm{~A} \mathrm{~cm}^{-2}$. This is a great advantage in seeking reliable kinetic and mechanistic information.

\section{Acknowledgements}

The authors acknowledge the financial support from TSB Project No: TP AE200089 and the involvement of the industrial partners ITM Power plc, Pera Innovation Ltd, and Teer Coating Ltd.

\section{References}

1 D. Pletcher and F. C. Walsh, Industrial Electrochemistry, Chapman and Hall, 1991.

2 K. Kinoshita, Electrochemical Oxygen Technology, Wiley, 1992.

3 A. B. La Conti and L. Swette, in Handbook of Fuel Cells, ed. W. Vielstich, A. Lamm and H. A. Gasteiger, Wiley, 2003, vol. 3, Part 3, p. 745.

4 C. H. Hamann, T. Ropke and P. Schmittinger, in Encyclopedia of Electrochemistry, ed. D. D. MacDonald and P. Schmuki, 2007, vol. 5 , p. 299.

5 Handbook of Fuel Cells, ed. W. Vielstich, A. Lamm and H. A. Gasteiger, Wiley, Parts 4 and 5, 2003, vol. 2.

6 D. E. Hall, J. Electrochem. Soc., 1985, 132, 41C.

7 D. E. Hall, J. Electrochem. Soc., 1983, 130, 317.

8 D. A. Corrigan, J. Electrochem. Soc., 1987, 134, 377.

9 M. D. Merrill and R. C. Dougherty, J. Phys. Chem. C, 2008, 112, 3655.

10 A. K. Shwarsctein, Y. S. Hu, G. D. Stucky and E. W. McFarland, Electrochem. Commun., 2009, 11, 1150.

11 S. M. Jasem and A. C. C. Tseung, J. Electrochem. Soc., 1979, 126, 1353.

12 J. O’M. Bockris and T. Otagawa, J. Phys. Chem., 1983, 87, 2960.

13 F. Jiao and H. Frei, Angew. Chem., Int. Ed., 2009, 48, 1841.

14 P. A. Nelson, J. M. Elliott, G. S. Attard and J. R. Owen, Chem. Mater., 2002, 14, 524.

15 P. A. Nelson and J. R. Owen, J. Electrochem. Soc., 2003, 150, A1313.

16 P. Cox, Ph.D. Thesis, University of Southampton, 1989.

17 A. J. Arvia and D. Posadas, Encyclopedia of Electrochemistry of the Elements, ed. A. J. Bard, Marcel Dekker, vol. 3, 1975.

18 E. L. Miller and R. E. Rocheleau, J. Electrochem. Soc., 1997, 144, 3072 . 